\title{
The Relationship of Employee Engagement, Organizational Commitment and Organizational Citizenship Behavior
}

\author{
Pir Sajad Ullah*, Waseef Jamal, Muhammad Naeem \\ Institute of Management Sciences, Peshawar, Pakistan
}

\begin{abstract}
This study aims to examine the relationship between employee engagement, organizational commitment and organizational citizenship behavior. With the help of literature, current study developed two hypotheses regarding employee engagement, organizational commitment and organizational citizenship behavior. Educational sector was selected for the conducting of this study. Structured closed ended questionnaire was used for the collection of data. Using correlation and regression analysis, the study results showed that there is a significant positive relationship between employee engagement and organizational commitment and furthermore confirmed that there is a significant positive relationship between employee engagement and organizational citizenship behavior. This study provided beneficial insights about employee engagement in the education sector of Pakistan. The study concludes by discussing limitations and future research directions.
\end{abstract}

\section{Introduction}

In this modern world organizations agree that a skillful workforce is the most important asset of any organization and turnover of such workforce is a big problem for most organization. Hence, attracting and retaining such skilled employees is a big challenge for todays organization, because the skilled employees have usually more job options (Joo and Mclean, 2006). However, employees having necessary skills are sufficient to help the organization to accomplish its objectives and goals. It is vital for the organization to manage these skilled employees for active and better performance (Cho and McLean, 2009).

According to Ulrich and Smallwood (2007) for the success of organization, it is necessary that it must have employees with three qualities; commitment or engagement, competence and contribution. Performance of the employees not only depends on the cognitive skills and competence, however employee performance also depends on the emotional response of the worker to the organizational works. Moreover, it has been empirically tested that engaged employees who are engaged in their jobs and organization are less motivated through financial rewards and highly motivated through non-financial rewards. Thus, employee engagement is one of the most crucial topics in the field of management and HRD (Gebauer et al., 2008).

In the past few years, researchers have given greater attention to employee engagement. Organizations can increase their productivity and achieve

*Corresponding author.

Email: pirsajjad20@yahoo.com

http://www.jbrc.pk business outcomes through superior technology, wellorganized work processes and through employee engagement. Different research studies have suggested that organizational outcomes and performance depend on employee engagement (Harter et al., 2002; Saks, 2006). Though, previous literature highlighted that employee engagement level is decreasing while the level of disengagement in the United States has been on the rise (Saks, 2006). For example, about half of the total employees in the United States are reportedly disengaged bearing the annual productivity makes 300 billion losses (Saks, 2006). Sorenson (2013) of employee shows that in United States and Canada the engaged employees are $29 \%$ and not engaged employees are $54 \%$ and actively disengaged are $18 \%$.

According to Flade (2003) the estimated cost of British economy due the disengagement of the employees is ranging from 37 billion to 38 billion per year. While in Japan only nine percent of the workforce is engaged and loss of productivity is about 232 billion dollar (Wellins et al., 2005). According to the recent survey of Sorenson (2013) worldwide result of 142 countries shows that only $13 \%$ of workforce is engaged and $63 \%$ is not engaged and $24 \%$ are disengaged actively.

In Pakistan the level of engaged employees is only $15 \%$, while not engaged employees are $68 \%$ and $16 \%$ of employees are actively disengaged (Sorenson, 2013). However, these findings reveal that companies pay high cost due to the disengagement of the employees. In the past few years employee engagement has taken a fundamental part in the effectiveness of an organiza- 
tion. It is due to the fact that engagement has considerable impact on the employee outcomes and organizational outcomes. Those organizations which have engaged employees, will have committed employees and there will be low chances of turnover. The organization will increase its profitability and productivity and will have loyal and satisfied customer due the result of those engaged employees (Kompaso and Sridevi, 2010). However, there are several studies which have provided an empirical evidences that employee with high engagement level will also have improved performance (Echols and Tsai, 2005; Jeung, 2011; Luthans and Peterson, 2002; Smythe, 2008; Tasker, 2004; Walters, 2008; Whiteoak et al., 2006). To the best of researchers knowledge, this area remained ignored in under developing country like Pakistan.

\section{Literature Review}

Employee engagement is one of the most popular concepts in the field of Human Resource Development. From the past two decades the idea of engagement is initiated in the organization and management literature (Simpson, 2009). Employee engagement plays a key role in the success of any organization. Therefore, considerable attention was given to the term engagement and researchers are giving more consideration on the roles of employee engagement for the organizational success in order to attain competitive advantage.

\subsection{Employee Engagement}

Employee engagement is considered a novel concept in the field of HRD but it is greatly promoted by different consultant companies (Wefald and Downey, 2009). Different scholars and researchers are agreed upon the basic concept of employee engagement, which helps explain the behavior of employees at work; however, scholars present different definitions of employee engagement.Kahn (1990) defined employee engagement as the harnessing of Organization members selves to their work roles; in engagement, people employ and express themselves physically, cognitively, and emotionally during role performances. Whereas, on the contrary, disengagement is defined as uncoupling of selves from work roles in which the individual take out themselves physically, cognitively and emotionally while acting that job. Thus, Kahn stressed that engagement is psychological and physical presence of employee while performing the job.

\subsection{Organizational Citizenship Behaviors (OCB)}

The notion of work behavior comes under the scope of job responsibility and has obtained a lot of attention since the book Organizational Citizenship Behavior: The Good Solider Syndrome was published by Organ (1988). During 1983-1988 about 13 papers were published related to OCB and other related constructs and about 122 papers were published during 1993-1998 (Podsakoff et al., 2000). It shows that OCB is highly important in the business literature. However, it shows that the concept of OCB is not new in the corporate world, the notion of OCB started from works of the earlier scholars Barnard (1938) and then later on to work of Katz (1964) and lastly to the work of LePine et al. (2002).

There are several definitions of OCB which are presented in the following:

Chester Bernard observed the phenomena of OCB for the first time in 1930 and called it extra-role behaviors (Barnard, 1938) while later on citizenship term was used by Katz (1964) to represent those worker which express extra-role behaviors.

OCB is elaborated as Individual behavior that is discretionary, not directly or explicitly recognized by the formal reward system, and that in the aggregate promotes the effective functioning of the organization (Organ, 1988).

Later on in 1997, Organ defined organization citizenship as performance that supports the social and psychological environment in which task performance takes place (Organ, 1997).

There are some researchers who have tried to define OCB from their own lenses, and this definition shows quite resemblance with the works of Organ and his colleagues. Niehoff and Moorman (1993) described OCB as behavior which is not incorporated in the job description of the employees. OCB is also known as good soldier syndrome (Organ, 1988). It is the behavior which is showed by the committed employees of the organization. OCB consists of Punctuality of the employees, helping other colleagues of the organization, presenting innovating ideas, volunteer work in the organization (Organ, 1988). It also has the tendency to stop an individual from undesirable action like complaining, arguing and finding fault with others (Organ, 1988).

Components of Organizational citizenship behaviors Organ (1988), argued that there are five components of OCB:

1. Altruism: Altruism means helping or helpfulness. Altruism is helping other members of the organization in performing their jobs.

2. Conscientiousness: It is a behavior of the employees that is out of the level of compulsory expectation; it differs from term altruism due to dissimilar targets. Its target can be departments 
or whole organization while the objective of altruism is only individual.

3. Sportsmanship: It refers to such behavior an individual manifests while bearing troublesome condition without grievances.

4. Courtesy: it refers to the behavior which helps other members to avert problems in advance, somewhat than helping somebody who is already in difficulties.

5. Civic virtue: It is the behavior of employees concerning contribution in organizational problems, like debating and talking about the organizational problems.

\subsection{Employee Engagement and OCB}

Employee engagement is considered one of significant predictors of organizational financial performance and triumph of any organization (Baumruk, 2004). It is also the fact that presently employee engagement is also declining as organizations and workers mutually tend to be more materialistic and vast engagement gap can be perceived at work places (Saks, 2006).

Employee engagement may lead to OCB as it emphasizes on the employee involvement and employee commitment which are not the explicit part of any employee job description.

Rich et al. (2010) examined that employee engagement is predictor of OCB. Employee engagement is related to OCB because it is based upon social exchange theory (SET) and the principle of mutual interest. OCB includes emotional components due to which employee perform OCB (Bennett and Robinson, 2000).

Ariani (2013) concluded that employee engagement is one of the possible predictors of OCB and employees who have a tendency to engage in helpful and responsible behaviors at work (i.e. OCB). Thus the first hypothesis is given as:

H1. There is a positive relationship between employee engagement and $O C B$.

\subsection{Organizational Commitment}

Organizational commitment is defined by Allen and Meyer as a psychological state that binds an employee to an organization, thereby reducing the incidence of turnover (Allen and Meyer, 1990). Mowday et al. (1982) defined organization commitment as the relative strength of an individuals identification with and involvement in a particular organization. The three components Model of organization commitment gained considerable popularity since its initiation (Wasti, 2005). The three components Model of organizational commitment includes: affective commitment, continuance commitment and normative commitment.
Employee with a high level of normative commitment feels that he/she ought to remain with the organization (p. 67). Among these three components of organizational commitment, affective commitment is considered being the most important one that has an influence on the employee behaviors within their organizations (Ueda, 2011). Consequently, employee with strong affective commitment is considered to have positive effect on the behaviors of the employees like OCB (Ueda, 2011).

\subsection{Employee Engagement and Organiza- tional Commitment}

Studies have been conducted in the developed countries which have found that there is a positive correlation between employee engagement and affective commitment (Richardsen et al., 2006). Llorens et al. (2007) found that organizational commitment increases with an increase in engagement level of employees and employee engagement enhances job satisfaction, and improves performance, higher attendance and makes turnover rates lower.

Similarly, a study was conducted by Saks (2006) amongst 102 employees of Canadian organizations to test the model of antecedents and consequences of employee engagement. The study shows that employee engagement plays a mediating role between the antecedents and consequences of the employee engagement. Affective commitment is one of the consequences of the employee engagement.

Agyemang and Ofei (2013) elaborated that employee engagement and organizational commitment are related positively. If employee engagement increases then organizational commitment can also be increased which helps achieve the organizational objectives. According to Blizzard (2002) engaged workforce is more loyal and highly committed to the organization. Similarly Jordaan and Rothmann (2005) also tested the same view and found the same result.

Consequently, employee engagement and organizational commitment are positively correlated to each other. Similarly Albdour and Altarawneh (2014) have found positive relationship between employee engagement and organizational commitment in the banking sector. Moreover, in Zimbabwe, Shoko and Zinyemba (2014) have worked on higher educational institutions in order to investigate the impact of employee engagement and organizational commitment. They found the similar result as by Albdour and Altarawneh (2014).

H2. There is a positive relationship between employee engagement and organizational commitment. 


\section{Theoretical framework}

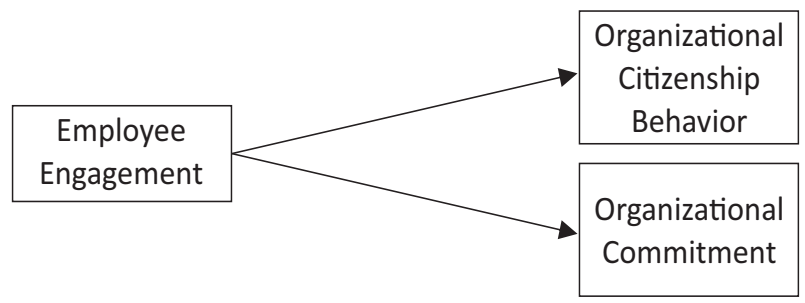

Figure 1: Theoretical Framework

\section{Research Methodology}

\subsection{Research Design}

The given study is correlation in nature. Primary data were collected through survey method. The aim of the research was to examine the correlation of employee engagement, OCB and employee commitment. Hence, correlation and quantitative research approach was considered suitable to collect primary data and address to the research questions.

The questionnaire consisted of 22 questions. Nine questions were used to measure employee engagement which was adopted from the paper of Saks (2006). The Cronbachs alpha value of the instrument was 0.943 . Organizational commitment was measured by the affective commitment and the scale developed by Rhoades et al. (2001); with Cronbachs alpha at 0.940. OCB was measured by the scale used by Lee and Allen (2002). The Cronbachs Alpha value of OCB was 0.86, showing the validity of the scale. A five point Likert scale was utilized for this study which allowed the participants to select from the five outcomes starting from strongly disagree to strongly agree.

\subsection{Population Frame}

Data were gathered from higher educational institutions of Khyber PakhtunKhwa (Malakand division).

Three universities of KPK (Malakand division) were selected through purposive sampling which in- clude UOM, UOS and Shaheed Benazir Bhutto University Sheringal (SBBUS). The rationale for the selection of these Universities was on the following importance.

1. University of Swat and SBBU Sheringal was selected because these universities were establish at the time of Taliban crisis, so the purpose of the selection was in order to find out the employees engagement level in such universities which was established in a difficult time.

2. University of Malakand was selected on basis that Taliban have targeted and attacked this University. The researcher is also interested to find the engagement level of the university which has passed through a difficult time.

\subsection{Sampling}

In the first step the researcher has found the list of universities of kpk which were established after 2000. There were fourteen universities which were established after 2000. Three universities (UOM, UOS \& SBBU) were selected through purposive sampling. In the second step the employees of universities are divided into two strata (1) Administration (2) faculty. The sample from the two strata was selected through disproportionate sampling.

The respondents of study include faculty members and administration of the three universities (UOM Chakdara, UOS \& SBBU Sheringal). Overall, 250 questionnaires were distributed among the employees these universities. From the participants 202 questionnaires were taken back with response rate of 80.2. However, 193 questionnaires were selected for the final analysis, rest of the questionnaires was incomplete, therefore were rendered useless.

\section{Results}

The collected data were analyzed according to the objective and hypotheses of the study. On the given data only three types of statistical analysis were performed i.e. correlation and sample regression.

Table 1: Correlation Analysis

\begin{tabular}{lc}
\hline & Employee Engagement \\
\hline & Pearson Correlation \\
\hline Organizational Commitment & $0.516^{* *}$ \\
Organizational Citizenship Behavior & $0.540^{* *}$ \\
${ }^{* *}$. Correlation is significant at the 0.01 level (2-tailed).
\end{tabular}


Table 2: Regression Analysis

\begin{tabular}{lcccccc}
\hline Predictor & \multicolumn{3}{c}{ Organizational Commitment } & \multicolumn{3}{c}{ OCB } \\
\hline & $\beta$ & $\mathbf{R}^{2}$ & $\mathbf{P}$ & $\beta$ & $\mathbf{R}^{2}$ & $\mathbf{P}$ \\
Employee Engagement & 0.516 & 0.266 & 0.000 & 0.54 & 0.292 & 0.000 \\
\hline
\end{tabular}

\subsection{Correlation Analysis}

Correlation refers to the relationship to the association or relationship between two variables. It measures the degree to which two sets of data are related or not. Table 1 shows the correlation analysis of the study.

Table 1 shows that there is a significant positive relationship among the variables, i.e. employee engagement, organizational commitment, OCB. The Pearson Correlation value between employee engagement and organizational commitment is 0.516 which shows that there is significant positive correlation. The significant value 0.01 shows that the relationship is significant.

The Pearson Correlation value between employee engagement and organization citizenship behavior is 0.540 which shows that there is also significant positive correlation between the variables. The significant value 0.01 shows that the relationship is significant.

\subsection{Regression Analysis}

Regression measures the amount of total variation in dependent variable due the change in independent variables. Table 2 shows Regression analysis of the study.

Regression measures the amount of total variation in dependent variable due the change in independent variables. The value of $R$ square is 0.266 or $26.6 \%$; which shows that there is almost 26.6 percent variation in the dependent variable (organizational commitment) due to the one unit change in independent variable (employee engagement). The beta value of independent variable (employee engagement) is 0.516 and at significant value of 0.00 . This beta value indicates the amount of change in dependent variable (organizational commitment) due the change in independent variable (employee engagement).

For employee engagement and OCB the value of $R^{2}$ is 0.292 which indicates that almost $29.2 \%$ change in dependent variable (organizational citizenship behaviors) is due the one unit change in independent variable (employee engagement).The beta value of independent variable (employee engagement) is 0.540 and at significant value of .000. This beta value indicates the change in dependent variable (organizational citizenship behavior) due the change in independent variable (employee engagement).

\section{Discussion}

Employee engagement has been an area of interest from last decade among the consultants and practitioners. However the contribution of employee engagement for organization product is still in question. This study has aimed to find out empirical support in favor of employee engagement as contributing factor for organization product. The study found that there is a significant positive relationship between employee engagement and organizational commitment with a correlation value of 0.51 at 0.01 , so we accept the first hypothesis of the study. In addition, the same relationship was found by Saks (2006). The same result was also found by Richardsen et al. (2006) and Llorens et al. (2007) who concluded that organizational commitment increases with an increase in engagement level of employees. Agyemang and Ofei (2013) and Blizzard (2002) have elaborated that those employees who have high engagement level are loyal and committed to the organization. Similarly, the same point of view was also approved by Jordaan and Rothmann (2005). Consequently, employee engagement and organizational commitment are correlated to each other and it has positive impact on each other. Similarly, Albdour and Altarawneh (2014) have also found the same relation in the Jordan banking sector. They found that job engagement is positively related to affective commitment ( $\mathrm{r}$ $=.436, \mathrm{p}, 0.01$ ) and organizational engagement is also positively related to affective commitment $(\mathrm{r}=.456, \mathrm{p}$, $0.01)$. As compared to the research of Albdour and Altarawneh (2014) no significant difference was found between both the studies rendering the values $(r=.516 . p$, 0.01 ). If we compare the regression analysis of the both studies the value of $\mathrm{R}$ is 0.293 while in this study it is 0.26 which is not a big difference. This small difference may be due to cultural differences or it may be due to difference in sectors or population.

The result of the study shows those employees who have high level of engagement are more committed to the organization. The result recommends the high level of engagement leads to high affective commitment.

The result of the study also concluded that there is also a significant positive correlation between employee engagement and OCB with a correlation value of 0.50 at 0.01 significant levels. So we accept our second hypothesis of the study. Similarly, the same result was also found by Allen and Meyer (1990), Saks (2006) 
and Ariani (2014). The study conducted by Ahmed et al. (2012) also argued that more enthusiastically an employee is engaged in his work there will be better chances to reveal organizational citizenship behaviors.

\subsection{Limitation and Future Research Recom- mendations}

This research contains a number of limitations. First, for a better result it is important to have a larger sample. This study is limited to academic sector and has been conducted only in education sector. However, the same can be conducted in other sectors i.e. banking sector, manufacturing sector, industrial sector, telecommunication sector etc.

Questionnaire has been used as a data collection tool so the same research can be conducted by using interview, focus group discussion for concrete results.

This study explores the association of employee engagement, Organizational Citizenship behavior and Organizational commitment from the context of less develop areas of Pakistan, so the same study can be conducted in other part of the world with different cultures context or other parts of Pakistan as well.

Lastly, other limitation is the sensitivity of the topic; the employees may be hesitant to express their solid negative emotions, as result participants may mark high engagement due the fear that the data will be not be kept confidential.

\section{References}

Agyemang, C. B. and Ofei, S. B. (2013). Employee work engagement and organizational commitment: A comparative study of private and public sector organizations in ghana. European Journal of Business and Innovation Research, 1(4):20-33.

Ahmed, N., Rasheed, A., and Jehanzeb, K. (2012). An exploration of predictors of organizational citizenship behaviour and its significant link to employee engagement. International Journal of business, humanities and technology, 2(4):99-106.

Albdour, A. A. and Altarawneh, I. I. (2014). Employee engagement and organizational commitment: Evidence from jordan. International Journal of Business, 19(2):192.

Allen, N. J. and Meyer, J. P. (1990). The measurement and antecedents of affective, continuance and normative commitment to the organization. Journal of occupational and organizational psychology, 63(1):1-18.

Ariani, D. W. (2013). The relationship between employee engagement, organizational citizenship behavior, and counterproductive work behavior. International Journal of Business Administration, 4(2):46.
Ariani, D. W. (2014). Relationship leadership, employee engagement, and organizational citizenship behavior. International Journal of Business and Social Research, 4(8):74-90.

Barnard, C. I. (1938). 1968. The functions of the executive.

Baumruk, R. (2004). The missing link: the role of employee engagement in business success.

Bennett, R. J. and Robinson, S. L. (2000). Development of a measure of workplace deviance. Journal of applied psychology, 85(3):349.

Blizzard, R. (2002). Employee engagement: For-profit versus not-for-profit hospitals. Gallup Poll Tuesday Briefing, pages $1-2$.

Cho, Y. and McLean, G. N. (2009). Leading asian countries' hrd practices in the it industry: a comparative study of south korea and india. Human Resource Development International, 12(3):313-331.

Echols, A. and Tsai, W. (2005). Niche and performance: The moderating role of network embeddedness. Strategic Management Journal, 26(3):219-238.

Flade, P. (2003). Great britains workforce lacks inspiration. Gallup Management Journal, 11:1-3.

Gebauer, J., Lowman, D., and Gordon, J. (2008). Closing the engagement gap: How great companies unlock employee potential for superior results. Penguin.

Harter, J. K., Schmidt, F. L., and Hayes, T. L. (2002). Businessunit-level relationship between employee satisfaction, employee engagement, and business outcomes: a metaanalysis.

Jeung, C.-W. (2011). The concept of employee engagement: A comprehensive review from a positive organizational behavior perspective. Performance Improvement Quarterly, 24(2):49-69.

Joo, B.-K. and Mclean, G. N. (2006). Best employer studies: A conceptual model from a literature review and a case study. Human resource development review, 5(2):228-257.

Jordaan, G. and Rothmann, S. (2005). Work engagement of academic staff in south african higher insfitufions. WorkWell: Research Unit for People, Policy and Performance.

Kahn, W. A. (1990). Psychological conditions of personal engagement and disengagement at work. Academy of management journal, 33(4):692-724.

Katz, D. (1964). The motivational basis of organizational behavior. Systems Research and Behavioral Science, 9(2):131146.

Kompaso, S. M. and Sridevi, M. S. (2010). Employee engagement: The key to improving performance. International journal of business and management, 5(12):89.

Lee, K. and Allen, N. J. (2002). Organizational citizenship behavior and workplace deviance: the role of affect and cognitions. Journal of applied psychology, 87(1):131. 
LePine, J. A., Erez, A., and Johnson, D. E. (2002). The nature and dimensionality of organizational citizenship behavior: a critical review and meta-analysis.

Llorens, S., Schaufeli, W., Bakker, A., and Salanova, M. (2007). Does a positive gain spiral of resources, efficacy beliefs and engagement exist? Computers in human behavior, 23(1):825841.

Luthans, F. and Peterson, S. J. (2002). Employee engagement and manager self-efficacy. Journal of management development, 21(5):376-387.

Mowday, R. T., Porter, L. W., and Steers, R. M. (1982). Employee-organization linkage. The psychology of commitment absenteism, and turn over_ Academic Press Inc. London.

Niehoff, B. P. and Moorman, R. H. (1993). Justice as a mediator of the relationship between methods of monitoring and organizational citizenship behavior. Academy of Management journal, 36(3):527-556.

Organ, D. W. (1988). Organizational citizenship behavior: The good soldier syndrome. Lexington Books/DC Heath and Com.

Organ, D. W. (1997). Organizational citizenship behavior: It's construct clean-up time. Human performance, 10(2):85-97.

Podsakoff, P. M., MacKenzie, S. B., Paine, J. B., and Bachrach, D. G. (2000). Organizational citizenship behaviors: A critical review of the theoretical and empirical literature and suggestions for future research. Journal of management, 26(3):513-563.

Rhoades, L., Eisenberger, R., and Armeli, S. (2001). Affective commitment to the organization: The contribution of perceived organizational support. Journal of applied psychology, 86(5):825.

Rich, B. L., Lepine, J. A., and Crawford, E. R. (2010). Job engagement: Antecedents and effects on job performance. Academy of management journal, 53(3):617-635.

Richardsen, A. M., Burke, R. J., and Martinussen, M. (2006). Work and health outcomes among police officers: The mediating role of police cynicism and engagement. International Journal of Stress Management, 13(4):555.
Saks, A. M. (2006). Antecedents and consequences of employee engagement. Journal of managerial psychology, 21(7):600-619.

Shoko, M. and Zinyemba, A. Z. (2014). Impact of employee engagement on organizational commitment in national institutions of higher learning in zimbabwe. International Journal of Advanced Research in Management and Social Sciences, 3(9):255-268.

Simpson, M. R. (2009). Engagement at work: A review of the literature. International journal of nursing studies, 46(7):1012-1024.

Smythe, J. (2008). Engaging employees. Real-life Leadership.

Sorenson, S. (2013). How employee engagement drives growth. Gallup business journal, 1.

Tasker, J. (2004). Engagement equals productivity. Personnel Today, 5:8-9.

Ueda, Y. (2011). Organizational citizenship behavior in a japanese organization: The effects of job involvement, organizational commitment, and collectivism. Journal of Behavioral Studies in Business, 4:1.

Ulrich, D. and Smallwood, N. (2007). Building a leadership brand. Harvard Business Review, 85(7/8):92.

Walters, D. (2008). How i made a difference employee engagement. Personnel Today, 23:33.

Wasti, S. A. (2005). Commitment profiles: Combinations of organizational commitment forms and job outcomes. Journal of Vocational Behavior, 67(2):290-308.

Wefald, A. J. and Downey, R. G. (2009). Job engagement in organizations: fad, fashion, or folderol? Journal of Organizational Behavior, 30(1):141-145.

Wellins, R. S., Bernthal, P., and Phelps, M. (2005). Employee engagement: The key to realizing competitive advantage. Development Dimensions International, 5:1-31.

Whiteoak, J. W., Crawford, N. G., and Mapstone, R. H. (2006). Impact of gender and generational differences in work values and attitudes in an arab culture. Thunderbird International Business Review, 48(1):77-91. 